\title{
МОДЕЛЮВАННЯ ДИНАМІКИ НАВАНТАЖУВАЛЬНИХ РЕЖИМІВ РОБОТИ ГІДРОНАСОСНОЇ СТАНЦЇ З ЕЛЕКТРОПРИВОДОМ ЗА ЖИВЛЕННЯ ВІД ВІТРОЕЛЕКТРИЧНОЇ УСТАНОВКИ 3 СИНХРОННИМ ГЕНЕРАТОРОМ
}

\author{
П.Ф. Васько, докт. техн. наук, С.Т. Пазич, аспірант \\ Інститут відновлюваної енергетики НАН України, \\ 02094, вул. Гната Хоткевича, 20А, м. Київ, Україна.
}

Гідронасосні станиії з електроприводом та живленням від вітроелектричних установок знайшли застосування на територіях, віддалених від розподільчих електромереж. Досвід експлуатації таких станцій засвідчує суттєвий вплив наявності пульсаиій швидкості вітру на їх продуктивність. В рамках изього дослідження розроблена математична модель динаміки зміни подачі води багатоагрегатною гідронасосною станцією з електроприводом від асинхронних двигунів з короткозамкненою обмоткою ротора за живлення від вітроелектричної установки з синхронним генератором з урахуванням стохастичної складової зміни швидкості вітру. Дослідження динамічних процесів здійснюється на 10-и хвилинному інтервалі осереднення швидкості вітру, щзо є стандартизованою величиною для оцінки потужності вітроелектричної установки за збурень вітрового потоку. Модель являє собою систему нелінійних диферениійних рівнянь, шьо описує взаємодію двох інериійних складових єдиної аероелектрогідродинамічної системи. Периа інериійна складова містить в собі вітротурбіну та синхронний генератор, а друга - асинхронний двигун та гідронасос. Взаємний вплив одної інериійної складової на іншу здійснюється через електричний зв'язок між генератором та двигуном через лінію електропередачі разом з трансформаторними підстаниіями. Визначення параметрів механічного обертального руху інериійних складових виконувалось в припущенні про квазістаціонарність електромагнітних процесів в статорних і роторних контурах генератора та двигуна. Розрахунок їх електромагнітних моментів здійснювався з використанням еквівалентних заступних електричних схем обладнання 3 урахуванням змінної частоти обертання та довільної кількості гідроагрегатів у складі станції. Представлені результати розрахунків динаміки подачі гідронасосної станції потужністю 1 МВт в складі 5 гідроагрегатів за електрожсивлення від вітроустановки з синхронним явнополюсним генератором такої ж потужності за швидкості вітру менше номінального значення, рівному та більшому за номінальне значення. Вони надають можливості оиінки динамічних властивостей процесу перетворення кінетичної енергії вітру в потенціальну енергію води, накопиченої в басейні акумуляторі. На сьогодні отримані результати набувають важливого значення в зв 'язку з необхідністю інтеграції значних потужностей вітроелектростанцій до складу електроенергетичних систем. Бібл. 26, табл. 3, рис. 8.

Ключові слова: вітротурбіна, гідронасос, динаміка, інериійність, подача, синхронний генератор, стохастичність.

\section{MODELING DYNAMICS LOADING MODES WORK OF THE HYDRO-PUMP STATION WITH THE ELECTRIC DRIVE FROM POWER SUPPLY OF THE WIND ELECTRIC INSTALLATION WITH THE SYNCHRONOUS GENERATOR}

\author{
P. Vasko, doctor of technical science, S. Pazych, graduate student \\ Institute of Renewable Energy of the National Academy of Sciences of Ukraine, \\ 02094, 20A Hnata Khotkevycha St., Kyiv, Ukraine.
}

\begin{abstract}
Hydro-pumped hydropower stations have been used in areas remote from the distribution grids. The experience of operating such stations demonstrates a significant impact of wind speed ripples on their performance. In the framework of this study, a mathematical model of the dynamics of water flow change by a multi-unit hydro-pump station with electric drive from asynchronous motors with a short-circuited rotor winding with power from a wind electric installation with a synchronous generator with a stochastic component of wind speed change was developed. The study of dynamic processes is carried out at a 10-minute interval of averaging wind speed, which is a standardized value for estimating the power of a wind electric installation for disturbance of wind flow. The model is a system of nonlinear differential equations describing the interaction of two inertial components of a single aero-electrohydro-dynamic system. The first inertial component includes a wind turbine and a synchronous generator, and the second - an induction motor and a hydraulic pump. The interaction of one inertial component with another is effected through the electrical connection between the generator and the motor through the transmission line together with the transformer substations. The parameters of mechanical rotational motion of inertial components were determined using the assumption of quasi-stationarity of electromagnetic processes in the stator and rotor circuits of the generator and the motor. The calculation of their electromagnetic moments was carried out using equivalent alternate electrical circuits of the equipment, taking into account the variable speed and an arbitrary number of hydro units in the station. The results of calculations of the dynamics of the supply of a 1 MW hydro-pump station of 5 hydropower units with a synchronous pole generator of the same power at a wind speed less than the nominal value equal to and greater than the nominal value are presented. They provide an opportunity to evaluate the dynamic properties of the process of converting wind kinetic energy into the potential energy of water stored in a pool battery. The results obtained today are becoming increasingly important in view of the need to integrate significant wind power capacity into electricity systems. Ref. 26, tab. 3, fig. 8.
\end{abstract}

Keywords: wind turbine, hydraulic pump, dynamics, inertia, flow, synchronous generator, stochasticity. 


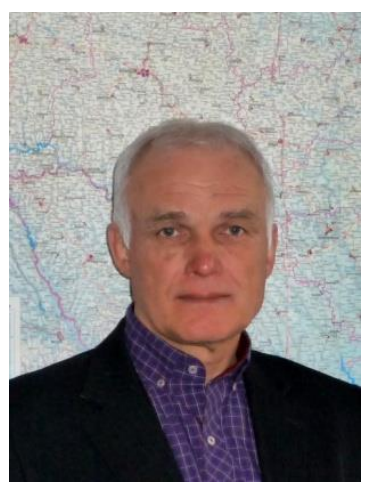

П.Ф. Васько

P. Vasko

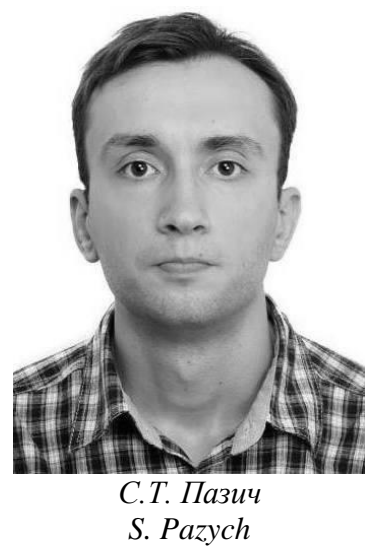

Відомості про автора: Доктор технічних наук за спеціальністю «Перетворення відновлюваних видів енергії», завідувач відділом гідроенергетики Інституту відновлюваної енергетики HAHУ

Освіта : Національний технічний університет України «Київський політехнічний інститут».

Наукова сфера: альтернативна енергетика, енергозбереження, перетворення відновлюваних видів енергії, мала гідроенергетика.

Публікації: 247.

ORCID: 0000-0001-8807-7173

Контакти: тел./факс: +38-044-206-28-09 e-mail: hydro@ive.org.ua

Відомості про автора: аспірант, молодший науковий співробітник відділу гідроенергетики Інституту відновлюваної енергетики НАНУ.

Освіта: Національний технічний університет України «Київський політехнічний інститут імені Ігоря Сікорського». Спеціальність «Нетрадиційні та відновлювані джерела енергії».

Наукова сфера: відновлювана енергетика.

Публікації: 12.

ORCID: 0000-0002-6310-9842

Контакти: тел./факс: +38-044-206-28-09 e-mail: hydro@ive.org.ua
Author information: Doctor of Technical Sciences majoring in «Renewable Energy Transformation», Head of Hydropower Department of the Institute of Renewable Energy NAS of Ukraine.

Education: National Technical University of Ukraine «Kyiv Polytechnic Institute».

Research area: alternative energy, energy saving, conversion of renewable energy types and installations based on them, small hydropower

Publications: 247.

ORCID: 0000-0001-8807-7173

Contacts: tel./fax: +38-044-206-28-09

e-mail: hydro@ive.org.ua

Author information: graduate student, junior researcher of Hydropower Engineering Department, Institute of Renewable Energy NAS of Ukraine. Education: National Technical University of Ukraine «Igor Sikorsky Kyiv Polytechnic Institute». Specialty "Nontraditional and renewable energy sources".

Research area: renewable energy

Publications: 12 .

ORCID: 0000-0002-6310-9842

Contacts: tel./fax:+38-044-206-28-09

e-mail: hydro@ive.org.ua

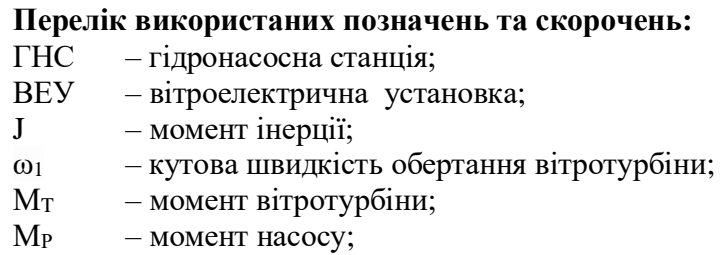

Вступ. Гідронасосні станції (ГНС) з електроприводом та живленням від вітроелектричних установок (ВЕУ) знайшли застосування в системах водопостачання об'єктів, розташованих на територіях, віддалених від розподільчих електромереж. Досвід побудови та експлуатації таких ГНС узагальнено в [1], де розглянуто варіанти реалізації живлення як від окремої ВЕУ для потужності в декілька кВт, так і від вітродизельних електростанції для потужності в декілька десятків кВт. Засвідчено суттєвий вплив стохастичної складової зміни швидкості вітру на продуктивність ГНС та необхідність застосування засобів автоматизації і регулювання навантажувальних режимів. Для малопотужних варіантів успішна експлуатація досягається шляхом застосування відцентрових регуляторів частоти обертання ВЕУ та гідравлічних клапанів зворотної дії подачі на-

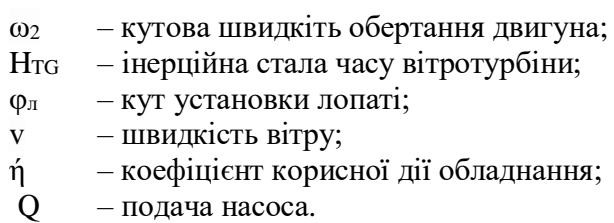

coca, проте зі збільшенням потужності виникає додаткова потреба в комутації величини навантаження, узгодженні режимів генерування і споживання енергії, вимірюванні і моніторингу параметрів, обробленні та передачі інформації. Експериментальне підтвердження наявності значних коливань генерованої потужності ВЕУ в натурних умовах експлуатації наведено також в $[2,3]$.

На сьогодні набуває актуальності питання накопичення енергії ВЕУ в басейнахакумуляторах гідроакумулювальних електростанцій [4-6]. В даному випадку рівень потужності таких комплексів може сягати десятків і сотень МВТ, тому знання динаміки навантажувальних режимів роботи гідронасосної станції з електроприводом за живлення від вітроелектричної установки набуває важливого значення. 
Постановка задачі полягає в розробленні математичної моделі динаміки зміни подачі води насосною станцією з електроприводом від асинХронних двигунів 3 короткозамкненою обмоткою ротора за живлення від вітроелектричної установки 3 синхронним генератором. Динаміка навантажувальних режимів роботи насосної станції зумовлена стохастичною складовою зміни швидкості вітру. Дослідження динамічних процесів здійснюється на 10-и хвилинному інтервалі осереднення швидкості вітру, що є стандартизованою величиною для оцінки потужності та динамічних процесів за збурень вітрового потоку $[7,8]$.

\section{Вихідні положення та припущення:}

- моделювання динаміки навантажувальних режимів роботи здійснюється для осередненого значення швидкості вітру $\left(\mathrm{v}_{\mathrm{o}}\right)$ в діапазоні 5$25 \mathrm{~m} / \mathrm{c}$;

- ВЕУ оснащена ідеальним регулятором кута повороту лопатей (фл) в функції швидкості вітру (v), що реалізує залежність

- зміна напряму подачі насоса $Q(t)$, зумовлена зміною швидкості вітру $\mathrm{v}(\mathrm{t})$ не допускається, тобто: $\mathrm{Q}(\mathrm{t}) \geq 0$;

- частота обертання ВЕУ та подача насоса в процесі роботи не перевищують 1,1 номінального значення;

- насосна станція містить в своєму складі декілька (n) однакових електронасосних агрегатів;

- подача насоса за сталого тиску води за- лежить лише від його кутової швидкості обертання $(\omega)$, тому визначення залежності $\mathrm{Q}(\mathrm{t})$ потребує розрахунку $\omega(\mathrm{t})$.

Теоретичні положення. Для моделювання подачі насоса за зміни швидкості вітру представимо об'єкт дослідження, як динамічну двомасову аероелектрогідродинамічну систему, структурна схема якої представлена на рис.1. Подача води $(\mathrm{Q})$ насосом $(\mathrm{P})$ в резервуар, розташованим на певній висоті, здійснюється в результаті його обертання асинхронним двигуном (D), який отримує живлення від синхронного генератора (G) вітроустановки по лінії електропередачі (L). Система функціонує під дією вітрового потоку, кінетична енергія якого перетворюється вітровою турбіною (Т) в механічну енергію обертового руху з подальшим іiі перетворенням в електричну енергію за допомогою синхронного генератора. Таким чином, одна із інерційних складових містить в собі вітротурбіну та синхронний генератор, а інша - асинхронний двигун та гідронасос. Взаємний вплив одної інерційної складової на іншу здійснюється через електричний зв'язок між генератором та двигуном. Структурна схема системи може містити також мультиплікатор в складі ВЕУ та редуктор в складі гідронасосного агрегата. Їх наявність не вносить нових принципових змін в роботу системи і може бути врахована при моделюванні застосуванням загальновживаних властивостей [9].

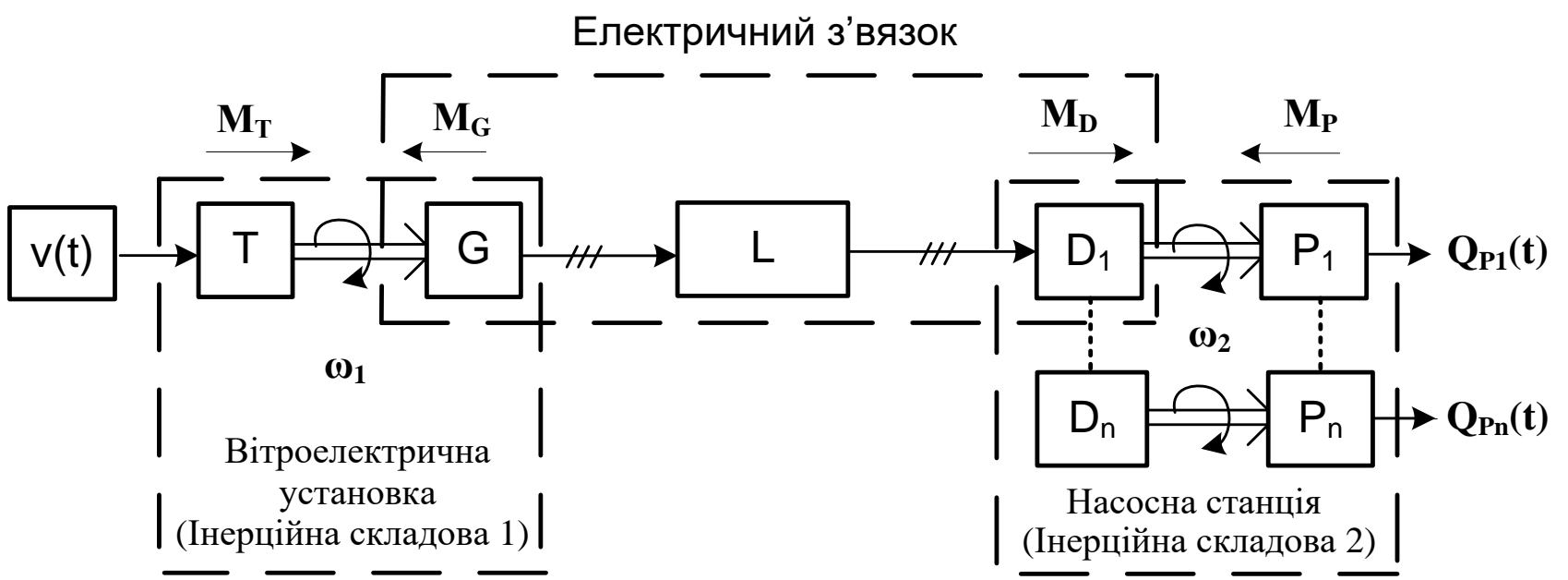

Рис. 1. Структурна схема двомасової аероелектрогідродинамічної системи.

Fig. 1. Structural diagram of two-mass aero-electric-hydro-dynanic system. 
Вихідне рівняння динаміки обертового руху першої інерційної складової запишемо, згідно закону Ньютона [9], відносно осі обертання вітротурбіни в наступному виді:

$$
\begin{gathered}
\mathrm{J}_{1} \frac{\mathrm{d} \omega_{1}}{\mathrm{dt}}=\mathrm{M}_{\mathrm{T}}\left(\mathrm{v}(\mathrm{t}), \omega_{1}, \varphi_{\mathrm{J}}(\mathrm{v})\right)- \\
-\mathrm{M}_{\mathrm{TT}}\left(\omega_{1}\right)-\mathrm{M}_{\mathrm{GT}}\left(\omega_{1}\right)-\mathrm{M}_{\mathrm{G}}\left(\omega_{1}, \omega_{2}, \mathrm{n}_{\mathrm{i}}\right), \\
\mathrm{v}(\mathrm{t})=\mathrm{v}_{\mathrm{CP}}+\mathrm{v}^{\prime}(\mathrm{t})=\mathrm{T}^{-1} \int_{0}^{\mathrm{T}} \mathrm{v}(\mathrm{t}) \mathrm{dt}+\mathrm{v}^{\prime}(\mathrm{t}), \\
\mathrm{J}_{1}=\mathrm{J}_{\mathrm{G}}+\mathrm{J}_{\mathrm{T}},
\end{gathered}
$$

де: $\mathrm{J}_{1}$ - сумарний момент інерції всіх обертових мас першої складової, приведений до осі вітроту-

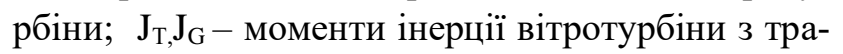
нсмісією та генератора відповідно; $\omega_{1}-$ кутова швидкість обертання вітротурбіни; $\mathrm{M}_{\mathrm{T}}$ - аеромеханічний момент вітротурбіни; $\varphi_{л}-$ кут повороту лопатей вітротурбіни; $\mathrm{M}_{\mathrm{TT}}$ - момент механічних втрат в елементах трансмісії та на електроживлення пристрою поворота лопатей; $\mathrm{M}_{\mathrm{GT}}-$ момент втрат на тертя, вентиляцію, перемагнічування сталі, збудження генератора; $\mathrm{M}_{\mathrm{G}}$ - момент електромагнітний генератора; $\omega_{2}-$ кутова швидкість обертання насосів; $\mathrm{n}_{\mathrm{i}}$ - кількість одночасно підключених насосів до генератора $\left(\mathrm{n}_{\mathrm{i}}=1,2, \ldots, \mathrm{n}\right)$; $\mathrm{v}(\mathrm{t})$ - миттєве значення швидкості вітру на інтервалі осереднення; $\mathrm{v}_{\mathrm{CP}}$ - осереднене значення швидкості вітру; $\mathrm{v}^{\mathrm{I}}(\mathrm{t})$ - стохастична складова швидкості вітру; Т - інтервал осереднення, рівний 600 c.

Відповідно запишемо вихідне рівняння динаміки обертового руху для другої інерційної складової відносно осі обертання двигуна насоса:

$$
\begin{gathered}
J_{2} \frac{d \omega_{2}}{d t}=M_{D}\left(U_{D}, \omega_{1}, \omega_{2}\right)- \\
-M_{D T}\left(\omega_{2}\right)-M_{P T}\left(\omega_{2}\right)-M_{P}\left(\omega_{2}\right), \\
J_{2}=J_{D}+J_{P},
\end{gathered}
$$

де: $\mathrm{J}_{2}$ - сумарний момент інерції всіх обертових мас другої складової, приведений до осі двигуна; $\mathrm{J}_{\mathrm{D}}, \mathrm{J}_{\mathrm{P}}$ - момент інерції двигуна та насоса відповідно, $\omega_{2}$ - кутова швидкість обертання двигуна; $\mathrm{M}_{\mathrm{D}}$ - момент електромагнітний двигуна; $\mathrm{U}_{\mathrm{D}}$ - напруга на клемах двигуна; $\mathrm{M}_{\mathrm{DT}}$ - момент механічних втрат двигуна (тертя та вентиляція); МРт - момент втрат гідронасоса; $\mathrm{M}_{\mathrm{P}}$ - момент гідродинамічний насоса.

Вирази (1),(2) являють собою, в сукупності, систему диференційних рівнянь, яка описує в загальному випадку взаємний вплив двох інерцій- них складових одна на одну, зумовлений наявністю стохастичної складової швидкості вітру. Для роз'язку системи необхідно визначити всі функціональні залежності від часу та кутової швидкості обертання. Стохастична складова швидкості вітру може бути лише змодельована, а характеристики обладнання - отримані від виробника. Проте доцільно зазначити, що на початковій стадії розроблення нових нетрадиційних проектів, коли виконується аналіз та вибір найбільш прийнятного варіанту, отримання зазначених вище характеристик $\epsilon$ вкрай проблематичним. Тому в таких випадках важливим етапом обгрунтування доцільності схемо-технічного рішення є моделювання і проведення обчислювальних досліджень нових режимів роботи та властивостей об'єкту.

Розглянемо визначення та моделювання відповідних характеристик обладнання, зазначеного на рис.1.

Стохастична складова швидкості вітру визначається шляхом моделювання амплітуди поривів випадковою величиною розподіленою по нормальному закону, а тривалості поривів - по ймовірнісному розподілу за законом Пуассона [10]. Практична реалізація стохастичної моделі здійснюється згідно положень [11].

Визначення моменту інерції вітроустановки потребує використання конкретної технічної документації. Його значення також може бути отримане на основі більш доступної інформації про інерційну сталої часу вітроустановки $\left(\mathrm{H}_{\mathrm{TG}}\right)$ в каталогах фірм-виробників. Орієнтовне значення $\mathrm{H}_{\mathrm{TG}}$, отримане авторами даної статті для широкої зміни номінальних потужностей сучасних ВЕУ, наведено у графічній формі на рис.2. Формула для розрахунку моменту інерції наступна:

$$
\mathrm{J}_{2}=\mathrm{H}_{\mathrm{TG}} \frac{\mathrm{N}_{\mathrm{T}}^{\mathrm{nom}}}{\left(\omega_{1}^{\mathrm{nom}}\right)^{2}},
$$

де: nom - ідентифікатор номінального значення, $\mathrm{N}_{\mathrm{T}}$ - потужність вітротурбіни.

Механічна характеристика вітротурбіни $\mathrm{M}_{\mathrm{T}}\left(\mathrm{v}(\mathrm{t}), \omega_{1}, \varphi_{\mathrm{r}}(\mathrm{v})\right)$ та закон керування кутом повороту лопатей в функції швидкості вітру можуть бути розраховані та змодельовані згідно основних положень вітротехніки [12,13] 3 застосуванням універсальної аеродинамічної характеристики $[14,15]$.

Моделювання механічної характеристики насосної станції і іiї подачі будемо здійснювати за 
результатами досліджень насосного режиму роботи гідроакумулювальної електростанції, висвітлених в [16], та за даними [17] для потужного відцентрового насосу. Вони виявились практично ідентичними в відносних одиницях і наведені на рис.3. Доцільно зазначити наявність малого діапазону можливої зміни частоти обертання нижче номінального значення для забезпечення подачі насосу $\mathrm{Q} \geq 0$. Значення моментів інерції двигуна та насоса наводяться у відповідних каталогах.

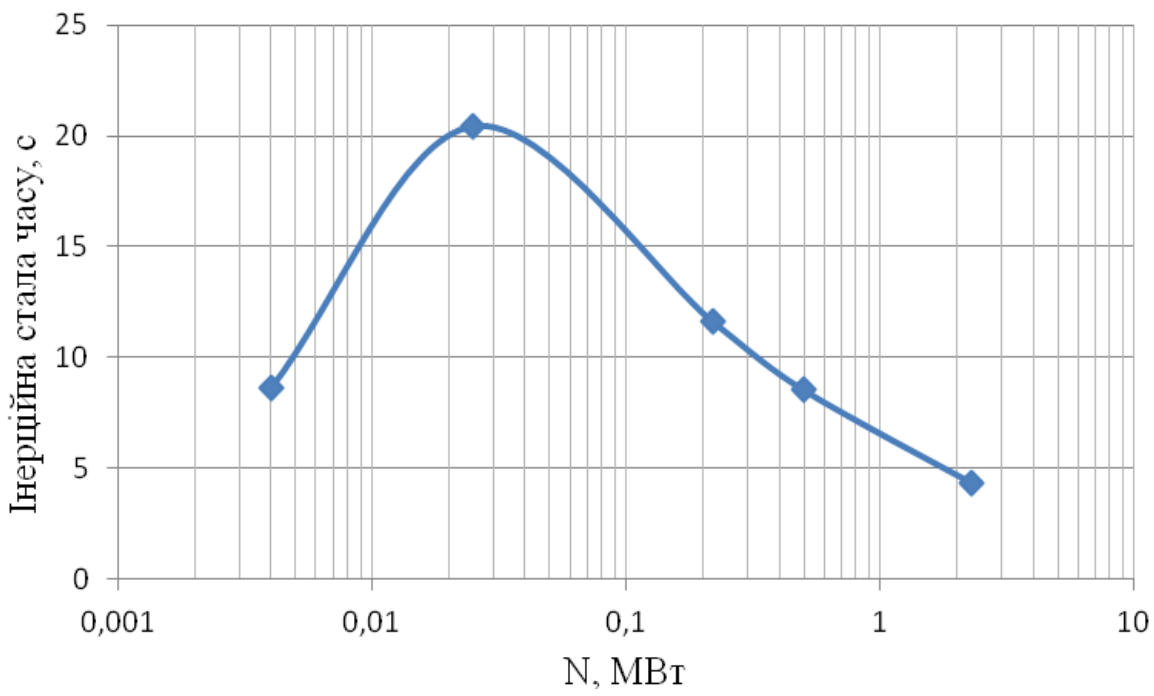

Рис. 2. Інерційна стала часу сучасних ВЕУ різної потужності.

Fig. 2. Inertia of constantly time of the modern wind turbine of different power.

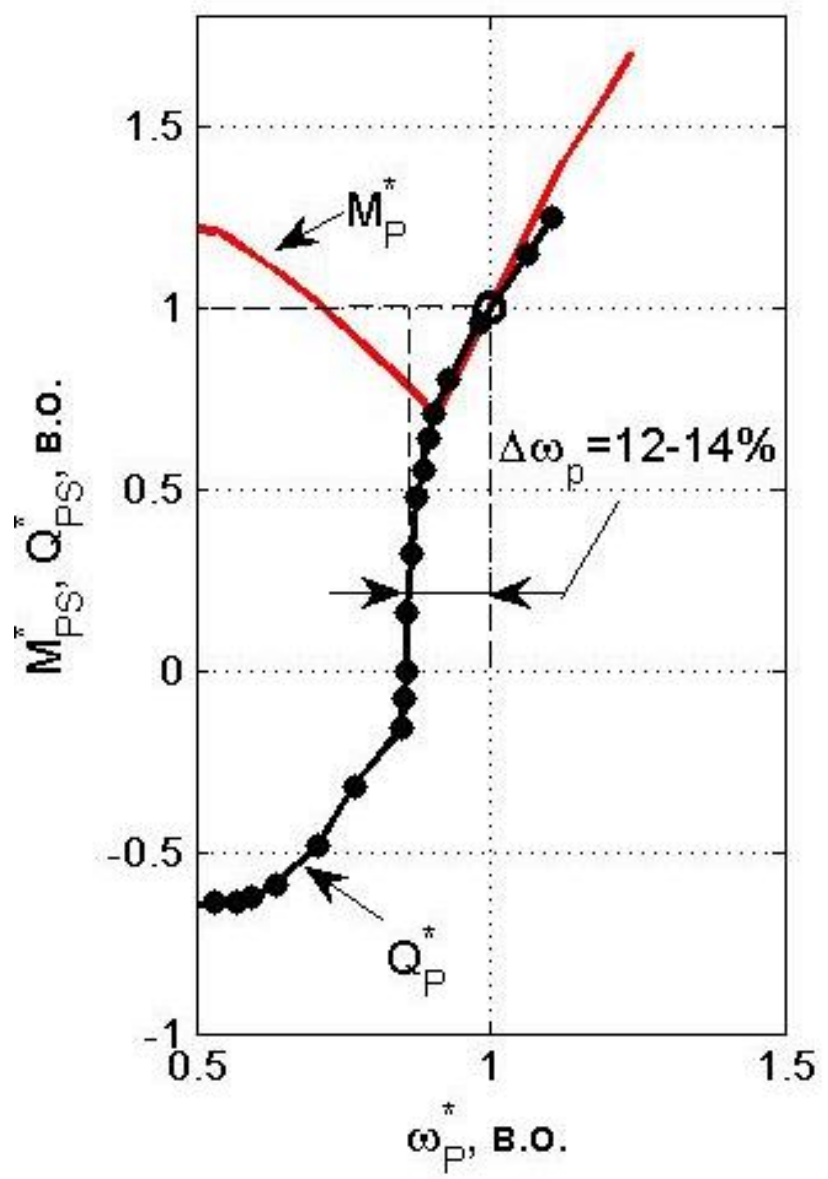

Рис. 3. Залежність моменту та подачі насоса від частоти обертання.

Fig. 3. Dependence of the torque and supply of the pump on the speed. 
Функціональні залежності для моментів

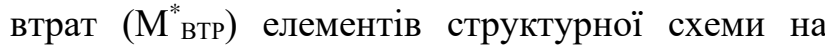
рис.1 представимо в наступному узагальненому вигляді:

$$
\begin{aligned}
& \mathrm{M}_{\mathrm{BTP}}^{*}\left(\omega^{*}, \mathrm{M}^{*}\right)=\beta_{0}+\beta_{1} \omega^{*}+ \\
& +\beta_{2}\left(\omega^{*}\right)^{2}+\beta_{3}\left(\omega^{*}\right)^{3}+\beta_{4} \mathrm{M}^{*}, \\
& \mathrm{M}^{*}=\frac{\mathrm{M}}{\mathrm{M}^{\mathrm{nom}}}, \omega^{*}=\frac{\omega}{\omega^{\mathrm{nom}}},
\end{aligned}
$$

де: $(*)$ - ідентифікатор відносних значень, $\beta_{0,1, \ldots 4}$ - коефіцієнти пропорційності, що визначаються за паспортними даними обладнання.

Визначення параметрів механічного обертального руху інерційних складових будемо виконувати в припущенні про квазістаціонарність електромагнітних процесів в статорних і роторних контурах генератора та двигуна. 3 урахуванням прийнятого допущення, розрахунок їх електромагнітних моментів в (1), (2) може бути здійснений $з$ використанням еквівалентних заступних електричних схем [18]. Згідно 3 теоретичними положеннями аналізу процесів в електричних машинах [19] визначення електромагнітних моментів доцільно реалізовувати також в відносних одиницях стосовно номінального значення, що i було зроблено в подальшому викладенні.

Електричний зв'язок між інерційними складовими будемо визначати 3 використанням еквівалентної електричної заступної схеми генератора, лінії електропередачі разом 3 трансформаторними підстанціями та двигунів (рис.4). Заступні схеми обладнання відповідають загальноприйнятим $[20,21]$ для номінальної частоти генерування електроенергії. Зміна частоти обертання ВЕУ зумовлює також зміну електрорушійної сили генератора, індуктивних опорів заступної схеми, а відповідно і електромагнітний момент двигунів насосних агрегатів, що враховано на схемі шляхом застосування додаткових множників $\omega_{1}{ }^{*}$ та $\omega_{2}{ }^{*}$.

На рис.4 наведена заступна Т-подібна схема насосної станції з декількома одночасно ввімкненими асинхронними двигунами $\left(n_{i}\right)$ з короткозамкненою обмоткою ротора. У випадку застосування двигуна $з$ фазним ротором в схему вторинного контура необхідно внести додаткові зовнішні опори $[9,22]$.

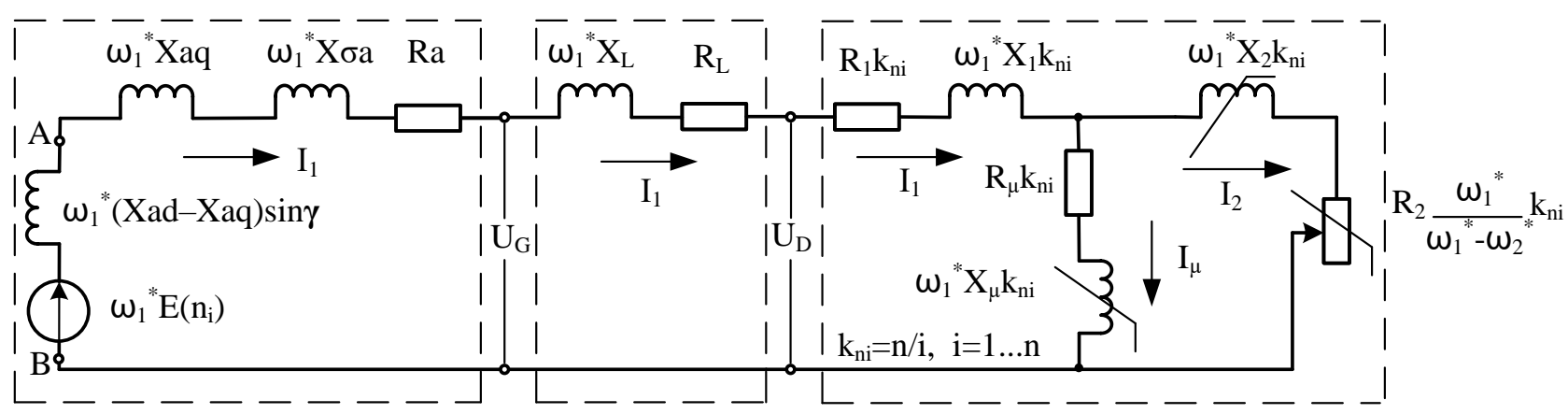

Синхронний генератор 3 електромагнітним збудженням
Лінія електропередач
Асинхронні двигуни насосної станції в кількості n одиниць

Рис. 4. Еквівалентна заступна схема електричного зв'язку ВЕУ 3 насосною станцією.

Fig. 4. Equivalent alternate circuit diagram of wind power installation with pumping station.

На схемі позначено: Е - електрорушійна сила генератора; $\mathrm{X}_{\mathrm{ad}}, \mathrm{X}_{\mathrm{aq}}$ - повздовжній та поперечний індуктивні опори реакції якоря; $\gamma$ - кут зсуву фаз між напругою $\mathrm{U}_{\mathrm{AB}}$ та струмом $\mathrm{I}_{1} ; \mathrm{X}_{\text {ба }}$ - індуктивний опір розсіювання обмотки якоря; $\mathrm{R}_{\mathrm{a}}$ - активний опір якоря $\mathrm{C} \Gamma ; \mathrm{R}_{\mathrm{L}}, \mathrm{X}_{\mathrm{L}}$ - активний і індуктивний опір ЛЕП; $\mathrm{R}_{1}, \mathrm{X}_{1}, \mathrm{R}_{2}, \mathrm{X}_{2}$ - активний та індуктивний опори обмоток статора та ротора АД; $\mathrm{R}_{\mu}, \mathrm{X}_{\mu}$ - активний і індуктивний опір контура намагнічування АД; $\mathrm{I}_{1}-$ струм якоря генератора та двигуна; $\mathrm{I}_{2}-$ струм в роторі АД; $\mathrm{I}_{\mu}-$ струм контура намагнічування.

Схема містить декілька нелінійних активних та реактивних опорів двигуна. Нелінійність індуктивного параметра контура намагнічування зумовлена зміною напруги і визначається експериментальним шляхом, або по нормалізованій характеристиці намагнічування. Зміна параметрів $\mathrm{R}_{2}, \mathrm{X}_{2}$ має місце для короткозамкнених обмоток ротора і може бути представлена наступним чином [22]: 


$$
\begin{gathered}
\mathrm{X}_{2}=\mathrm{X}_{2}^{\text {nom }}-\Delta \mathrm{X}_{2}|\mathrm{~s}|^{\beta} \frac{\mathrm{I}_{1}-1}{\mathrm{I}_{\Pi}-1}, \quad 1 \leq \mathrm{I}_{1} \leq \mathrm{I}_{\Pi}, \\
\mathrm{R}_{2}=\mathrm{R}_{2}^{\text {nom }}+\Delta \mathrm{R}_{2}|\mathrm{~s}|^{\beta} \frac{\mathrm{I}_{1}-1}{\mathrm{I}_{\Pi}-1}, \quad 1 \leq \mathrm{I}_{1} \leq \mathrm{I}_{\Pi}, \\
0,75 \leq \beta_{\mathrm{X}} \leq 1,25, \quad 1,5 \leq \beta_{\mathrm{R}} \leq 2,5, \\
\mathrm{~s}=\left(\omega_{1}^{*}-\omega_{2}^{*}\right) / \omega_{1}^{*} .
\end{gathered}
$$

де: $\mathrm{X}_{2}{ }^{\text {nom }}, \mathrm{R}_{2}{ }^{\text {nom }}$ - значення опорів статорної та роторної обмоток в номінальному режимі роботи; $\omega_{1}{ }^{*}, \omega_{2}{ }^{*}$ - кутова швидкість обертання вітротурбіни і двигуна в в.о.; $\mathrm{I}_{\Pi^{-}}$пускове значення струму; $\Delta \mathrm{X}_{2}, \Delta \mathrm{R}_{2}$ - приріст параметрів, відповідний струму $\mathrm{I}_{1}$.

Розрахунок струмів та напруг електричної схеми здійснюється відповідно до положень [23] в комплексних числах.. Значення електромагнітних моментів генератора і двигунів насосної станції та параметру $\gamma$ визначаються наступним чином:

$$
\begin{aligned}
& \mathrm{M}_{\mathrm{G}}=\left[\mathrm{I}_{1}^{2}\left(\mathrm{R}_{\mathrm{a}}+\mathrm{R}_{\mathrm{L}}+\mathrm{R}_{1} \mathrm{k}_{\mathrm{ni}}\right)+\right. \\
& \left.+\mathrm{I}_{2}^{2} \mathrm{R}_{2} \frac{\omega_{1}^{*}}{\omega_{1}^{*}-\omega_{2}^{*}} \mathrm{k}_{\mathrm{ni}}+\mathrm{I}_{\mu}^{2} \mathrm{R}_{\mu} \mathrm{k}_{\mathrm{ni}}\right] / \omega_{1}^{*} \text {, } \\
& \mathrm{M}_{\mathrm{D}}=\mathrm{I}_{2}^{2} \mathrm{R}_{2} \frac{\omega_{1}^{*}}{\omega_{1}^{*}-\omega_{2}^{*}} \mathrm{k}_{\mathrm{ni}} / \omega_{1}^{*} \text {, } \\
& \sin \gamma=\frac{\mathrm{a}}{\mathrm{b}}, \quad \mathrm{a}=\omega_{1}^{*}\left(\mathrm{X}_{\mathrm{aq}}+\mathrm{X}_{\sigma \mathrm{a}}+\mathrm{X}_{\mathrm{L}}\right)+\operatorname{Im}(\mathrm{ZD}), \\
& \mathrm{b}=\sqrt{\mathrm{a}^{2}+\left(\mathrm{R}_{\mathrm{a}}+\mathrm{R}_{\mathrm{L}}+\operatorname{Re}\left(\mathrm{Z}_{\mathrm{D}}\right)\right)^{2}},
\end{aligned}
$$

де: $\operatorname{Im}, \operatorname{Re}$ - уявна i дійсна складова комплексного числа відповідно; $Z_{D}$ - комплексний опір відносно клемних зажимів двигуна згідно схеми на рис.4.
Так як втрати енергії на нагрівання якорних обмоток генератора і двигунів та лінії електропередачі визначаються при розрахунку заступної електричної схеми, то вони повинні бути враховані відповідним чином при визначенні моментів втрат в рівняннях руху обох інерційних складових досліджуваної системи. Для даної постановки задачі, коли зміна частоти обертання в процесі тривалої експлуатації повинна знаходитися в діапазоні $(0,86$ - 1,1$)$ номінального значення, представимо моменти втрат, з урахуванням рівняння (5) та паспортних даних обладнання, наступними залежностями:

$$
\begin{gathered}
\mathrm{M}_{\mathrm{TT}}\left(\omega_{1}\right)=\beta_{0}=\left(1-\eta_{\mathrm{T}}^{\mathrm{nom}}\right), \\
\mathrm{M}_{\mathrm{GT}}\left(\omega_{1}\right)=\beta_{0}+\beta_{2}\left(\omega_{1}^{*}\right)^{2}= \\
=\left[0.7+0.3\left(\omega_{1}^{*}\right)^{2}\right]\left(1-\eta_{\mathrm{G}}^{\text {nom }}-\mathrm{Ra}\right), \\
\mathrm{M}_{\mathrm{DT}}\left(\omega_{2}\right)=\beta_{0}+\beta_{2}\left(\omega_{2}^{*}\right)^{2}= \\
=\left[0.5+0.5\left(\omega_{2}^{*}\right)^{2}\right]\left(1-\eta_{\mathrm{D}}^{\text {nom }}-\mathrm{R}_{1}-\mathrm{R}_{2}\right), \\
\mathrm{M}_{\mathrm{PT}}\left(\omega_{2}\right)=\beta_{0}+\beta_{3}\left(\omega_{2}^{*}\right)^{3}= \\
=\left[0.3+0.7\left(\omega_{2}^{*}\right)^{3}\right]\left(1-\eta_{\mathrm{P}}^{\text {nom }}\right),
\end{gathered}
$$

де: $\eta ́$ - коефіцієнт корисної дії обладнання, в.о.; $\mathrm{R}_{\mathrm{a}}, \mathrm{R}_{1}, \mathrm{R}_{2}$ - активний опір обладнання згідно схеми на рис. 4 , в.о.

Обмеження частоти обертання та потужності ВЕУ за зміни швидкості вітру здійснюється шляхом повороту лопатей вітротурбіни ідеальним регулятором, який реалізує узагальнений закон керування [14], наведений на рис.5. Узгодження потужності ВЕУ на інтервалі осереднення швидкості вітру та потужності насосної станції здійснюється шляхом зміни кількості ввімкнених електронасосних агрегатів.

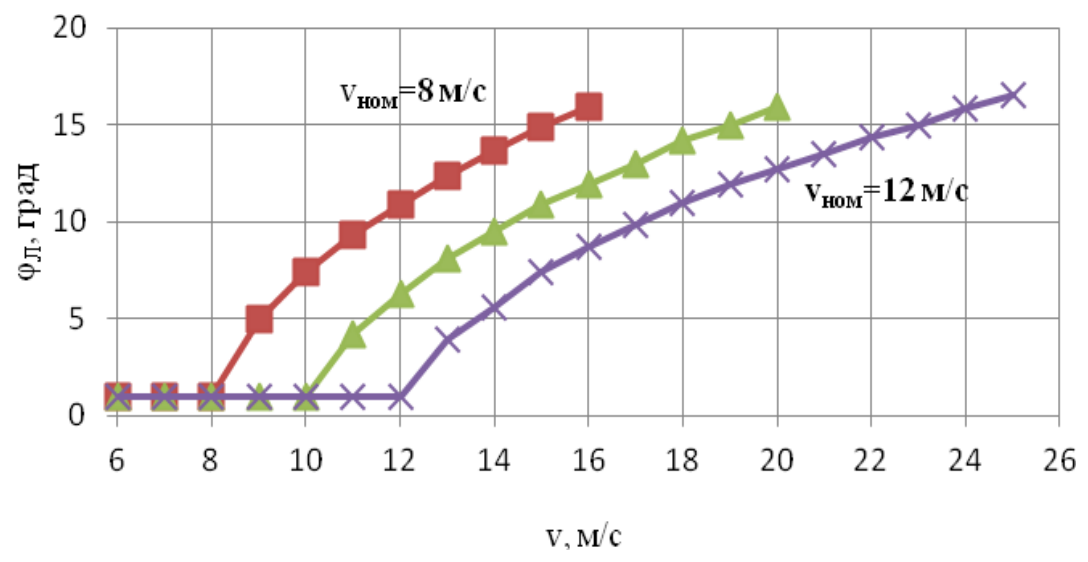

Рис. 5. Закон керування $\omega_{1}$ кутом повороту лопатей.

Fig. 5. The law of control $\omega_{1}$ the angle of rotation the blades. 
Таким чином, визначені всі складові системи нелінійних диференційних рівнянь (1), (2). Проте необхідно зазначити, що механічна характеристика вітротурбіни представлена в абсолютних величинах, а решта у відносних стосовно своїх номінальних значень. Так як взаємодія двох інерційних складових здійснюється через взаємозв'язок електромагнітних моментів генератора i двигуна, та базове значення моменту повинно бути одне для обох складових. В подальшому викладенні для зручності аналізу результатів за базове значення моменту для обох інерційних складових прийнято розрахункове значення еквівалентного номінального моменту насосної станції $\left(\mathrm{M}_{\mathrm{PS}}{ }^{\text {nom }}\right)$. Відповідним чином визначається i номінальне значення подачі станції:

$$
\mathrm{M}_{\mathrm{PS}}{ }^{\mathrm{nom}}=\mathrm{n} \mathrm{M}_{\mathrm{p}}{ }^{\mathrm{nom}}, \quad \mathrm{QPS}^{\text {nom }}=\mathrm{n}_{\mathrm{P}}{ }^{\mathrm{nom}} .
$$

Досвід дослідження аналогічних систем засвідчує доцільність представлення вихідних рівнянь у відносних одиницях стосовно базових значень $[22,24]$. Такий перехід спрощує вирази рівнянь в результаті звільнення від постійних коефіцієнтів, спрощує аналіз результатів розра- хунків, так як всі змінні представляються зручними числами в частках одиниці, що надає можливості для порівняння перебігу нестаціонарних процесів різних за потужністю систем.

Розрахункові дослідження та аналіз результатів. Розглянемо застосування розробленої математичної моделі для аналізу динаміки подачі води насосною станцією потужністю 1 МВт в складі 5 агрегатів за електроживлення від ВЕУ з синхронним явнополюсним генератором такої ж потужності. Номінальне значення швидкості вітру для установки складає $12 \mathrm{M} / \mathrm{c}$, а закон керування кутом повороту лопатями відповідає одному із варіантів на рис.5. Інерційні сталі часу ВЕУ та електронасосного агрегату складають 6 с. та 5 с. відповідно, ККД вітротурбіни дорівнює 98\%. Параметри генератора та двигуна наведені в табл. 1, 2. Залежність моменту і подачі станції від частоти обертання насосів наведені на рис.3, а значення ККД насоса дорівнює $87 \%$.

Залежність параметрів заступної схеми від кількості ввімкнених агрегатів у складі станції наведено в табл. 3.

Таблиця 1. Параметри синхронного генератора.

Table 1. Synchronous generator parameters.

\begin{tabular}{|c|c|c|c|c|}
\hline $\mathrm{R}_{\mathrm{a}}$, в.o. & $\mathrm{X}_{\mathrm{ad}}$, в.о. & $\mathrm{X}_{\mathrm{aq}}$, в.о. & $\mathrm{X}_{\sigma \mathrm{\sigma}}$, в.о. & ККД, \% \\
\hline 0.02 & 0.85 & 0.6 & 0.12 & 95 \\
\hline
\end{tabular}

Таблиця 2. Параметри асинхронного двигуна.

Table 2. Asynchronous motor parameters.

\begin{tabular}{|c|c|c|c|c|c|c|c|}
\hline $\mathrm{R}_{1, \text { B.o. }}$ & $\mathrm{X}_{1, \text { в.o }}$ & $\mathrm{R}_{2, \text { в.o }}$ & $\mathrm{X}_{2, \text { B.o. }}$ & $\mathrm{R}_{\mu}$, в.о. & $\mathrm{X}_{\mu}$, B.o. & $\mathrm{s}_{\mathrm{n}}, \%$ & ККД, \% \\
\hline 0,02 & 0,1 & 0,02 & 0,1 & 0.1 & 3.5 & 2,3 & 94 \\
\hline
\end{tabular}

Таблиця 3. Параметри заступної схеми для різної кількості агрегатів.

Table 3. The coefficient parameters of the scheme the number of units.

\begin{tabular}{|l|c|c|c|c|c|}
\hline Кількість ввімкнених агрегатів у складі насосної станції, $\mathrm{n}$ & 5 & 4 & 3 & 2 & 1 \\
\hline $\mathrm{k}_{\mathrm{ni}}$, в.о. & 1 & 1.25 & 1.66 & 2.5 & 5 \\
\hline Номінальні значення моменту та подачі насосної станції, в.о. & 1.0 & 0.8 & 0.6 & 0.4 & 0.2 \\
\hline Е, в.о. & 1.82 & 1.63 & 1.44 & 1.27 & 1.12 \\
\hline Напруга двигуна, в.о. & \multicolumn{5}{|l|}{1} \\
\hline
\end{tabular}


Розрахункові дослідження перебігу навантажувальних режимів 3 урахуванням стохастичної складової швидкості вітру проведено в середовищі Matlab Simulink з використанням математичних операторів для організації алгоритму розв'язку математичної моделі, блоку «Lookup Table» для введення графічних залежностей та графічного редактора для візуалізації динаміки зміни необхідних параметрів. Рішення нелінійної системи диференційних рівнянь обертового руху здійснювалось числовим методом Рунге-Кутти. Початкові значення досліджуваних змінних параметрів визначались на заданій градації осередненого значення швидкості вітру за умови $d \omega / d t=0$. В залежності від величини осередненого значення градації швидкості вітру змінювалась кількість ввімкнених насосів в складі станції відповідно від тих чи інших обмежень та обставин, наведених вище на початку статті.

Виконано аналіз кількісних результатів моделювання динаміки навантажувальних режимів роботи насосної станції для трьох випадків, які відповідають швидкості вітру менше номінального значення, рівному та більшому за номінальне значення.

В першому випадку було прийнято осереднене значення швидкості вітру $\mathrm{v}_{\mathrm{CP}}=7 \mathrm{~m} / \mathrm{c}$. Результат моделювання наведено на рис.6, де показано миттєві значення швидкості вітру, кута повороту лопатей ВЕУ та подачі насосної станції. За даного закону керування кутом повороту лопатей його значення на досліджуваному інтервалі часу не змінюється і дорівнює $1^{\circ}$, за якого вітротурбіна має найбільш можливу потужність при швидкостях вітру менше номінального значення (за винятком моменту часу на 280-ій секунді, коли відбувалось короткотривале включення механізму повороту лопатей). В складі станції працює лише один гідронасосний агрегат, подача якого нестабільна і характеризується наявністю пульсацій, коефіцієнт варіації яких менший за аналогічний для швидкості вітру. Проте осереднене значення подачі станції менше за номінальне значення одного насосу.
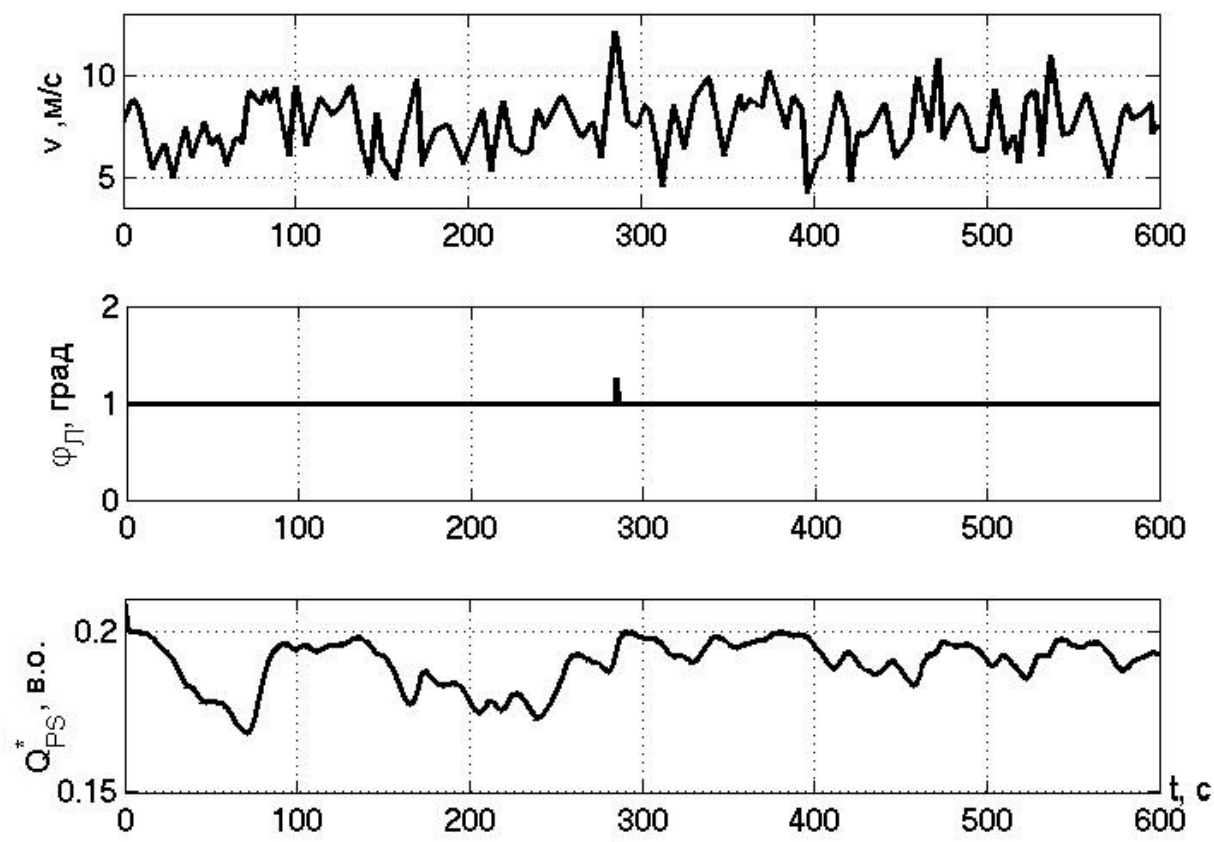

Рис. 6. Динаміка навантажувального режиму насосної станції за швидкості вітру $\mathrm{v}_{\mathrm{CP}}=7$ м/с.

Fig. 6. Dynamics of loading mode of the pumping station at wind speed $v_{\mathrm{Av}}=7 \mathrm{~m} / \mathrm{s}$.

Для другого випадку, за номінальної швидкості вітру $12 \mathrm{~m} / \mathrm{c}$, результати моделювання наведено на рис. 7. Кут повороту лопатей в процесі роботи змінюється від $1^{\circ}$ до $6^{\circ}$ в залежності від наявності поривів вітру. В складі станції працює 3 гідронасосні агрегати, подача яких досить стабільна на початковому інтервалі часу, проте менша за номіналь- ну. Більш того, навіть це значення в результаті спаду швидкості на 180-ій секунді стало від'ємним, що за прийнятих вище обмежень засвідчило втрату стійкості навантажувального режиму. Тобто, навіть за номінальної швидкості вітру досягнення 60 \% номінальної подачі гідронасосної станції можна вважати проблематичним. 

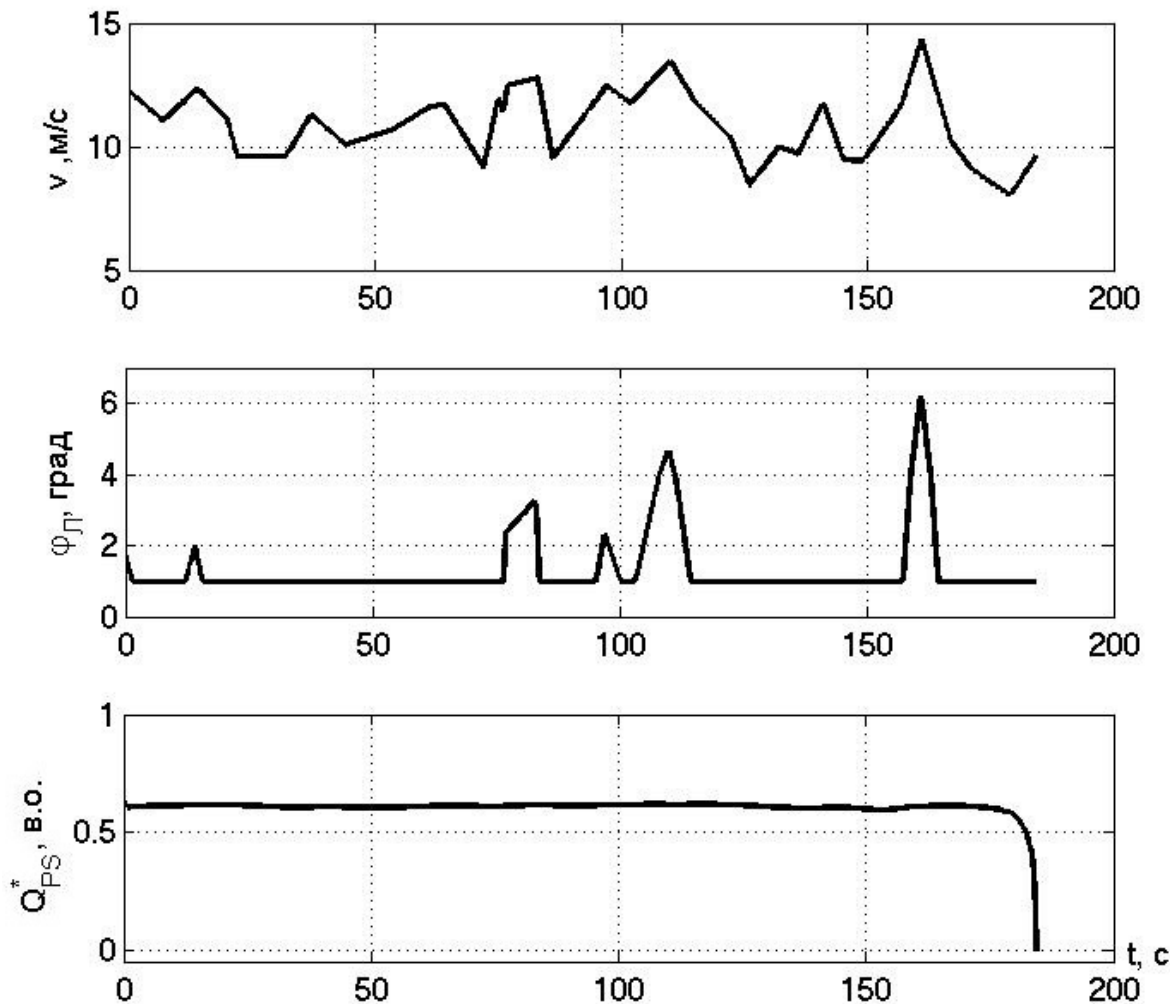

Рис. 7. Динаміка навантажувального режиму насосної станції за швидкості вітру $\mathrm{v}_{\mathrm{CP}}=12$ м/с.

Fig. 7. Dynamics of loading mode of the pumping station at wind speed $v_{A v}=12 \mathrm{~m} / \mathrm{s}$.
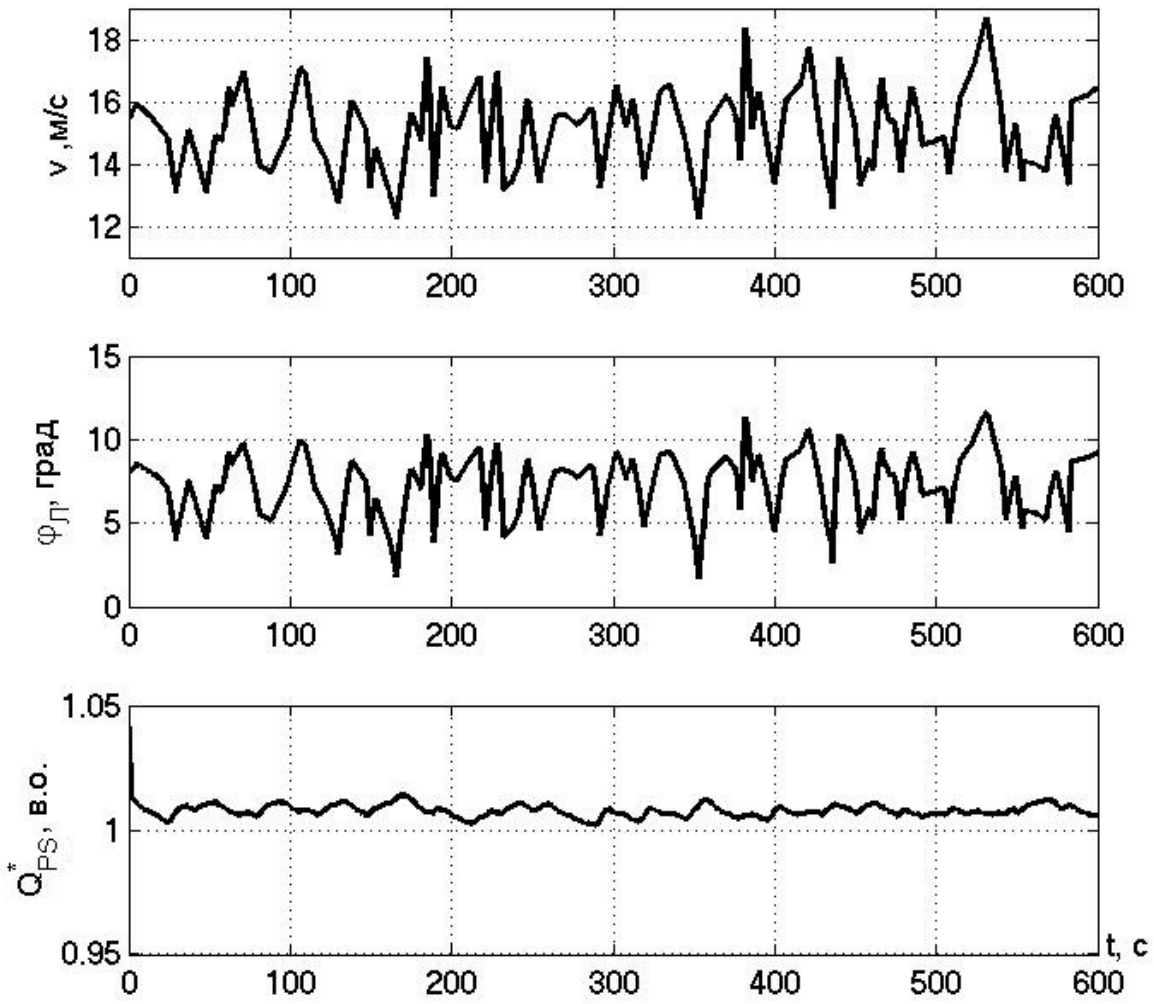

Рис. 8. Динаміка навантажувального режиму насосної станції за швидкості вітру vo=15 м/с.

Fig. 8. Dynamics of loading mode of the pumping station at wind speed $v_{A v}=15 \mathrm{~m} / \mathrm{s}$. 
За швидкостей вітру більше номінального значення досягається стабільний навантажувальний режим насосної станції з номінальною подачею завдяки регулюванню кута повороту лопатей, про що свідчать результати, наведені на рис. 8.

За результатами досліджень динаміки подачі насосної станції для різних осереднених значень швидкості вітру може бути визначена енергетична ефективність накопичення енергії ВЕУ в басейнах гідроакумулювальних електростанцій для довільного імовірнісного розподілу градацій швидкості вітру у відповідності 3 алгоритмами, розробленими в $[25,26]$.

Висновок. Розроблено математичну модель динаміки навантажувального режиму роботи гідронасосної станції з приводом насосів від асинхронних електродвигунів та живленням від вітроелектричної установки 3 синхронним генератором за стохастичної зміни швидкості вітру. Модель являє собою систему нелінійних диференційних рівнянь і описує динаміку обертового руху двомасової аероелектрогідромеханічної системи та надає можливості оцінки динамічних властивостей процесу перетворення кінетичної енергії вітру в потенціальну енергію води, накопиченої в басейні акумуляторі. В моделі враховано нелінійність аеродинамічної характеристики вітротурбіни від частоти обертання та кута повороту лопатей, нелінійність механічних характеристик гідронасосів від частоти обертання та нелінійність параметрів асинхронних електродвигунів від частоти обертання та напруги, довільну кількість електронасосів в складі станції.

1. Харитонов В.П. Автономные ветроэлектрические установки. М. ГНУ ВИЭСХ. 2006. 280 с.

2. Васько В.П., Васько П.Ф. Динамика нагрузочных режимов работы ветроэлектрической установки, обусловленная порывами ветра. Вісник Донбаської державної академії будівництва і архітектури. Зб. наук. праць. 2001. № 4(29). C. 140-144.

3. Васько П.Ф., Васько В.П., Даниленко О.І., Долюк B.B. Експериментальні дослідження режимів генерування та споживання реактивної потужності серійною вітроелектричною установкою з асинхронним генератором. Відновлювана енергетика. 2008. № 1(12). С. 34-38.

4. Jastrzębska G. El Hierro Renewable Energy Hybrid System: A Tough Compromise. Energies. 2018. № 11(10). 2812. 20 p. doi: 10.3390/en11102812.

5. Васько П.Ф., Вербовий А.П, Ібрагімова М.Р., Пазич C.T.. Гідроакумулювальні електростанції - технологічна основа інтеграції потужних вітро- та фотоелектричних станцій до складу електроенергетичної системи України. Гідроенергетика України. -2017. № 1-2. С. 20-25.

6. Ummels B.C., Pelgrum E., Kling W.L. Integration of large-scale wind power and the use of energy storage in the Netherlands. Renewable Power Generation. IET. 2008. № 2. Pp.34-46.

7. IEC 61400-1:2005 Wind Turbines - Part 1: Design requirements. International Standard. 2005. $179 \mathrm{p}$.

8. ДСТУ IEC 61400-12-2001. Системи турбогенераторні вітряні. Частина 12. Випробування вітряних турбін для визначення енергетичних характеристик. (IEC 61400-11:1998. IDT). Введ. 01.07.2003 р. К. Держспоживстандарт України. 2003. $31 \mathrm{c}$.

9. Воскобойник В.Э., Бородай В.А. Основы электропривода производственных машин и комплексов. Днепропетровський Государственный ВУЗ «НГУ». 2015. 121 с.

10. Денисенко Г.И., Васько П.Ф., Пекур П.П. Стохастическое моделирование параметров ветра для задач ветроэнергетики. Известия АН СССР. Энергетика и транспорт М. 1990. № 2. C. 109-115.

11. Васько П.Ф., Вербовий А.П., Пазич С.Т. Реалізація стохастичної моделі поздовжньої складової швидкості вітру для задач вітроенергетики. Відновлювана енергетика. 2017. № 3(50). C. 54-61.

12. Кривиов В.С., Олейников А.М., Яковлев А.И. Неисчерпаемая энергия. Кн. 2. Ветроэнергетика. Учебник. 2004. 519 с.

13. Абрамовский Е.P., Городько С.В., Свиридов Н.В. Аэродинамика ветродвигателей. Днепропетровск. Изд-во ДГУ $1987.220 \mathrm{c.}$

14. Пазич C.T. Апроксимація аеромеханічних характеристик вітрової турбіни вітроводонасосної установки в навантажувальних режимах роботи методом заміни змінних. Відновлювана енергетика. 2018. № 1(52). С. 62-69.

15. Пазич С.Т. Моделювання процесу заряду басейнуакумулятора гідроакумулювальної електростанції від вітроводонасосної установки. Відновлювана енергетика. 2019. № 2(57). C. 61-69. doi: 10.36296/1819-8058.2019.2(57).61-69.

16. Аршеневский Н.Н. Обратимые гидромашины для гидроаккумулирующих электростанций. М. Энергия. 1977. 240 с.

17. Степанов А. И. Центробежные и осевые насосы. М. Машгизд. 1960. $464 \mathrm{c.}$

18. Вольдек А.И. Электрические машины. 2-е изд. Л. Энергия. 1974. $840 \mathrm{c}$.

19. Важнов А.И. Переходные процессы в машинах переменного тока. Л. Энергия. 1980. $256 \mathrm{c}$.

20. Кравчик А.Э., Шлаф М.М., Афонин В.И. Асинхронные двигатели серии 4А. Справочник. М. Энергоиздат. 1982. $504 \mathrm{c}$.

21. Копылов И.П., Клокова К.К. Справочник по электрическим машинам. В 2 т. Т. 1. М. Энергоатомиздат. 1988.456 с.

22. Брыль А.А., Васько В.П., Васько П.Ф., Соловьев П.Б. Математическое моделирование нестационарных электромеханических процессов гидроэлектрических агрегатов малых ГЭС с различными типами генераторов при параллельной работе с электросистемой. Альтернативная энергетика и экология. 2013. № 3. С. 143-150.

23. Бессонов Л.А. Теоретические основы электротехники. Электрические цепи: Учеб. для электротехн., энерг. припоростроит. спец. вузов 9 изд. перераб. и доп. М. Высш. шк. $1996.638 \mathrm{c}$.

24. Mohanpurkar M., Ouroua A., Hovsapian R., Luo Y., Singh M., Muljadi E., Gevorgian V., Donalek P. Real-time co- 
simulation of adjustable-speed pumped storage hydro for transient stability analysis. Electric Power Systems Research. 2018. Vol. 154. Pp. 276-286. doi: 10.1016/j.epsr.2017.08.010.

25. Васько П.Ф. Розрахунок показників технічної ефективності застосування вітроелектричних установок за результатами строкових вимірювань швидкості вітру. Технічна електродинаміка. 2001. № 6. С. 45-49.

26. Брыль А.А., Васько П.Ф., Пекур П.П. Определение технических показателей эффективности использования ветроэлектрических агрегатов в Украине. Энергетика и электрификация. 1995. № 2. С. 48-51.

\section{REFERENCE}

1. Haritonov V.P. Avtonomnyie vetroelektricheskie ustanovki. [Autonomous wind power plants]. Moscow. 2006. 280 p. [in Russian].

2. Vasko V.P., Vasko P.F. Dinamika nagruzochnyih rezhimov rabotyi vetroelektricheskoy ustanovki, obuslovlennaya poryivami vetra. [Dynamics of loading modes of the windelectric installation, caused by gust of wind]. Bulletin of the Donbas State Academy of Civil Engineering and Architecture. Collection of scientific work. 2001. № 4(29). Pp. 140-144. [in Ukrainian].

3. Vasko P.F., Vasko V.P., Danylenko O.I., Doliuk V.V. Eksperymentalni doslidzhennia rezhymiv heneruvannia ta spozhyvannia reaktyvnoi potuzhnosti seriinoiu vitroelektrychnoiu ustanovkoiu $\mathrm{z}$ asynkhronnym heneratorom. [Experimental studies of the modes of generation and consumption of reactive power by a serial wind-driven installation with an asynchronous generator]. Vidnovluvana energetika. 2008. № 1(12). Pp. 34-38. [in Ukrainian].

4. Jastrzębska, G. El Hierro Renewable Energy Hybrid System: A Tough Compromise. Energies. 2018. № 11(10). 2812. 20 p. doi: 10.3390/en11102812. [in English].

5. Vasko P.F., Verboviy A.P., IbragImova M.R., Pazych S.T. GIdroakumulyuvalnI elektrostantsiyi - tehnologIchna osnova Integratsiyi potuzhnih vItro- ta fotoelektrichnih stantsIy do skladu elektroenergetichnoyi sistemi Ukrayini. [Pumped hydroelectric energy storage - technological basis of integration of powerful wind and photoelectric power stations into the power system of Ukraine]. Hydropower of Ukraine. 2017. № 1-2. Pp. 20-25. [in Ukrainian].

6. Ummels B.C., Pelgrum E., Kling W.L. Integration of large-scale wind power and the use of energy storage in the Netherlands. Renewable Power Generation. IET. 2008. № 2. Pp.34-46. [in English].

7. IEC 61400-1:2005 Wind Turbines - Part 1: Design requirements. International Standard. 2005. 179 p. [in English].

8. IDSTU IEC 61400-12-2001. Systemy turboheneratorni vitryani. Chastyna 12. [Wind turbine generator systems. Part 12]. Wind turbine power performance testing. (IEC 6140011:1998. IDT). Vved. 01.07.2003. K. Gospotrebstandart Ukrainy. 2003. 31 p. [in Ukrainian].

9. Voskoboynik V.E., Boroday V.A. Osnovyi elektroprivoda proizvodstvennyih mashin i kompleksov. [Fundamentals of electric drive of production machines and complexes]. Dnepropetrovsk. State University «NSU». 2015. 121 p. [in Russian].

10. Denisenko G.I., Vasko P.F., Pekur P.P. Stohasticheskoe modelirovanie parametrov vetra dlya zadach vetroenergetiki. [Stochastic simulation of wind parameters for wind power projects]. Bulletin of the Academy of Sciences of the USSR Energy and Transport. 1990. № 2. Pp. 109-115. [in Russian].

11. Vasko P.F., Verbovyi A.P., Pazych S.T. Realizatsiia stokhastychnoi dvoparametrychnoi modeli pozdovzhnoi skladovoi shvydkosti vitru dlia zadach vitroenerhetyky. [Implementation of a stochastic two-parameter model of the longitudinal component of the wind speed for wind power problems]. Vidnovluvana energetika. 2017. № 3(50). Pp. 54-61. [in Ukrainian].

12. Krivtsov V.S., Oleynikov A.M., Yakovlev A.I. Neischerpaemaya energiya. Kn. 2. Vetroenergetika [Inexhaustible energy. B. 2. Wind power]. Textbook. 2004. 519 p. [in Russian].

13. Abramovskiy E.R., Gorodko S.V., Sviridov N.V. Aerodinamika vetrodvigateley. [Aerodynamics of wind turbines]. Dnepropetrovsk. Publisher DGU. 1987. 220 p. [in Russian].

14. Pazych S.T. Aproksimatsiya ayeromekhanichnikh kharakteristik vitrovoï turbini vitrovodonasosnoï ustanovki v navantazhuvalnikh rezhimakh roboti metodom zamini zminnikhs. [Approximation of aeromechanical characteristics of the wind turbine of a wind pump installation in the load operation modes by the method of changing the variables]. Vidnovluvana energetika. 2018. № 1(52). Pp.62-69. [in Ukrainian].

15. Pazych S.T. Modeliuvannia protsesu zariadu baseinuakumuliatora hidroakumuliuvalnoi elektrostantsii vid vitrovodonasosnoi ustanovky. [Modeling of the charge process of the upper reservoir of the pump hydroelectric energy storage from the wind pump installation]. Vidnovluvana energetika. 2019. № 2(57). Pp. 61-69. doi: 10.36296/18198058.2019.2(57).61-69. [in Ukrainian].

16. Arshenevskyi N.N. Obratymыe hydromashynы dlia hydroakkumulyruiushchykh эlektrostantsyi. [Reversible hydraulic machines for pumped hydroelectric energy storage]. Leningrad, Energia. 1977. 240 p. [in Russian].

17. Stepanoff A.I. Tsentrobezhnyie I osevyienasosyi. [Centrifugal and axial flow pumps]. Moscow. Mashgiz. 1960. 464 p. [in Russian].

18. Voldek A.I. Elektricheskie mashiny. [Electric machines]. 2 edition. L. Energy. 1974. 840 p. [in Russian].

19. Vazhnov A.I. Perehodnyie protsessyi $\mathrm{v}$ mashinah peremennogo toka. [Transients in alternating current machines]. Leningrad. Energia. 1980. 256 p. [in Russian].

20. Kravchik A.E., Shlaf M.M., Afonin V.I. Asinhronnyie dvigateli serii 4A. [Electric Machine Reference 4A]. Reference book. Moscow. Energoizdat. 1982. 504 p. [in Russian].

21. Kopyilov I.P., Klokova K.K. Spravochnik po elektricheskim mashinam. V 2 t. / T. 1. [Electric Machine Reference. in 2 vol./Vol. 1]. Moscow. Energoatomizdat. 1988. 456 p. [in Russian].

22. Bryl A.O., Vasko V.P., Vasko P.F., Solovyov P.B. Matematicheskoye modelirovaniye nestatsionarnykh elektromekhanicheskikh protsessov gidroelektricheskikh agregatov malykh GES s razlichnymi tipami generatorov pri parallel'noy rabote s elektrosistemoy. [Mathematical modeling of non-stationary electromechanical processes of hydroelectrical hardware for small hydro power stations with different types of generators at parallel functioning with electric system]. Alternative Energy and Ecology ISJAEE. 2013. № 3. Pp. 143-150.

23. Bessonov L.A. Teoreticheskie osnovyi elektrotehniki. Elektricheskie tsepi: Ucheb. dlya elektrotehn., energ., pripo- 
rostroit. spets. vuzov -9 izd., pererab. i dop. [Theoretical Foundations of Electrical Engineering. Electric circuits]. Moscow. High school. 1996. 638 p. [in Russian].

24. Mohanpurkar M., Ouroua A., Hovsapian R., Luo Y., Singh M., Muljadi E., Gevorgian V., Donalek P. Real-time co-simulation of adjustable-speed pumped storage hydro for transient stability analysis. Electric Power Systems Research. 2018. Vol. 154. Pp. 276-286. doi: 10.1016/j.epsr. 2017.08.010. [in English].

25. Vasko P.F. Razrakhunok pokaznykiv tekhnichnoyi efektyvnosti zastosuvannya vitroelektrychnykh ustanovok za rezul'tatamy strokovykh vymiryuvan' shvydkosti. [Calculation of the technical efficiency of the application of wind power installations based on the results of term velocity measurements].Technical electrodynamics. 2001. №6. Pp.4549. [in Ukrainian].

26. Bryl A.A., Vasko P.F. Pekur P.P. Opredelenie tehnicheskih pokazateley effektivnosti ispolzovaniya vetroelektricheskih agregatov $v$ Ukraine. [Definition of technical indicators of efficiency of use the wind-electric aggregates in Ukraine]. Energy and electrification. 1995. № 2. Pp. 48-51. [in Russian].

\section{МОДЕЛИРОВАНИЕ ДИНАМИКИ НАГРУЗОЧНЫХ РЕЖИМОВ РАБОТЫ ГИДРОНАСОСНОЙ СТАНЦИИ С ЭЛЕКТРОПРИВОДОМ С ПИТАНИЕМ ОТ ВЕТРОЭЛЕКТРИЧЕСКОЙ УСТАНОВКИ С СИНХРОННЫМ ГЕНЕРАТОРОМ}

П.Ф. Васько, doctor of technical science, С.Т. Пазыч, graduate student

Институт возобновляимой энергетики НАН Украины, 02094 ул. Гната Хоткевича, 20А, м. Киев, Украина.

Гидронасосные станции с электроприводом и питанием от ветроэлектрических установок нашли применение на территориях, удаленных от распределительных электросетей. Опьтт эксплуатации таких станциий свидетельствует сущеественное влияние наличии пульсащий скорости ветра на их производительность. В рамках этого исследования разработана математическая модель динамики изменения подачи водь многоагрегатного Гидронасосн станциией с электроприводом от асинхронных двигателей с короткозамкнутой обмоткой ротора питанимая от ветроэлектрической установки с синхронным генератором с учетом стохастической составляющей изменения скорости ветра. Исследование динамических прочессов осуществляется на 10-и минутном интервале осреднения скорости ветра, является стандартизированной величиной для оченки мощности ветроэлектрической установки по возмущений ветрового потока. Модель представляет собой систему нелинейных дифференциальных уравнений, описывающей взаимодействие двух инерционных составляющих единой аероелектрогидродинамичнои системь Первая инериионная составляющая содержит в себе ветротурбину и синхронный генератор, а вторая - асинхронный двигатель и гидронасос. Взаимное влияние одной инерционной составляющей на другую осуществляется через электрический связь между генератором и двигателем через линию электропередачи вместе с трансформаторными подстанциями. Определение параметров механического вращательного движения инеричонных составляюших выполнялось в предположении о квазистационарнисть электромагнитных прочессов в статорных и роторных контурах генератора и двигателя. Расчет их электромагнитных моментов осуществлялся с использованием эквивалентных заступни электрических схем оборудования с учетом переменной частоты вращения и произвольного количества гидроагрегатов в составе станции. Представлены результаты расчетов динамики подачи гидронасосной станции мощностью $1 \mathrm{MBm}$ в составе 5 гидроагрегатов за электропитание от ветроустановки с синхронным явнополюсним генератором такой же мощности при скорости ветра меньше номинального значения, равном и большем номинального значения. Они предоставляют возможности оченки динамических свойств прочесса преобразования кинетической энергии ветра в потенщииальную энергию воды, накопленной в бассейне аккумуляторе. На сегодня получены результаты приобретают важное значение в связи с необходимостью интеграции значительных мощностей ветроэлектростанций в состав электроэнергетических систем. Библ. 8, табл. 8, рис. 4.

Ключевые слова: ветротурбина, гидронасос, динамика, инерционность, подача, синхронньй генератор, стохастичность. 